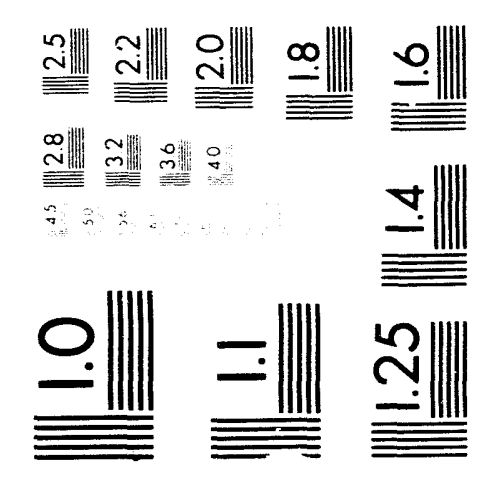



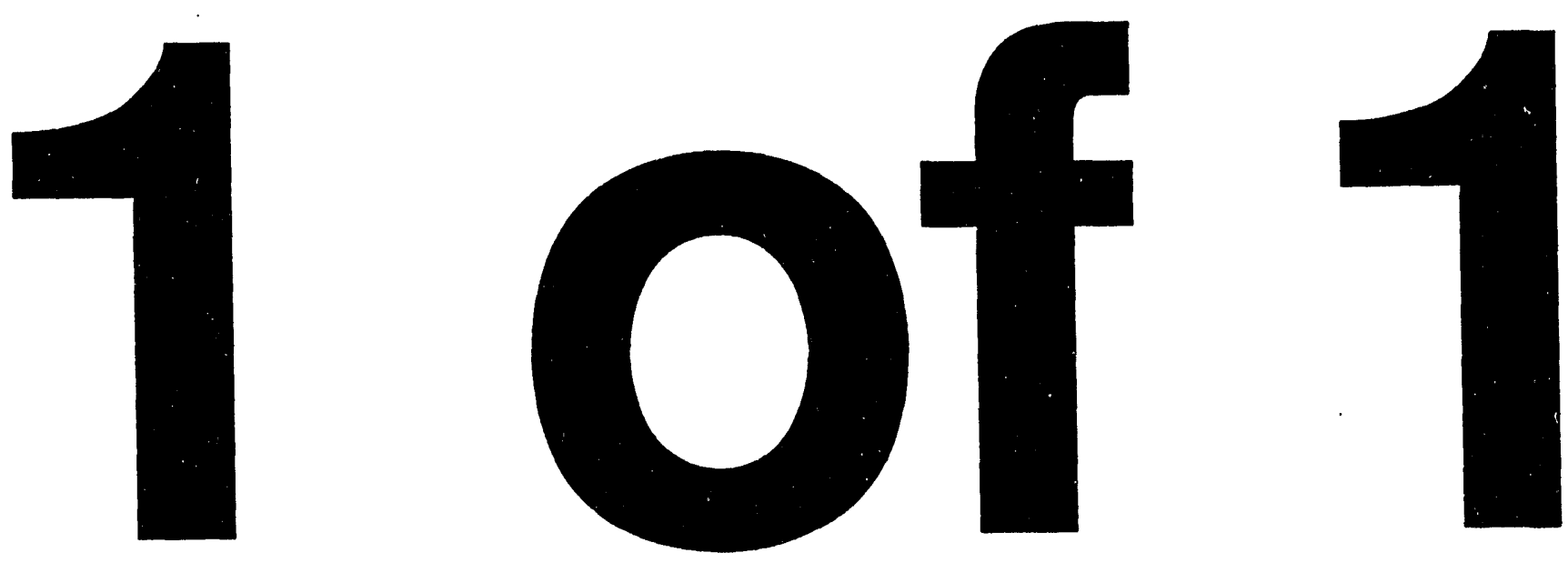


\title{
Colorado ECONOMIC IMPACT StUdY ON THE URANIUM MILL TAILINGS REMEDIAL ACTION Project IN Colorado
}

\author{
Draft
}

November 1993

\section{DISCLAIMER}

This report was prepared as an account of work sponsored by an agency of the United States

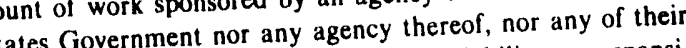
Government. Neither the United States Government nor any agen legal liability or responsiemployees, makes any warranty, express or implied, or assum information, apparatus, product, or bility for the accuracy, completeness, or usefulness of any inforive privately owned rights. Referprocess disclosed, or represents that its use would not inf or service by trade name, trademark, ence herein to any specific commercial product, process, or ser imply its endorsement, recomence herein to ar otherwise does not necessarily constitute or imply its endorsement, The views mendation, or favoring by the United States Government or any agency thect those of the and opinions of authors expressed herein do not

United States Government or any agency thereof. 
This report has been reproduced from the best available copy. Available in paper copy and microfiche.

Number of pages in this report: 54

DOE and DOE contractors can obtain copies of this report from:

Office of Scientific and Technical Information

P.O. Box 62

Oak Ridge, TN 37831

(615) 576-8401

This report is publicly available from:

National Technical Information Service

Department of Commerce

5285 Port Royal Road

Springfield, VA 22161

(703) $487-4650$ 


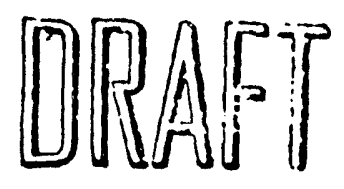

\section{COLORADO ECONOMIC IMPACT STUDY ON THE URANIUM MILL TAILINGS REMEDIAL ACTION PROJECT IN COLORADO}

\section{COLORADO STATE FISCAL YEAR 1993}

November 1993

Prepared for

U.S. Department of Energy UMTRA Project Office Albuquerque, New Mexico

Prepared by

Jacobs Engineering Group Inc.

Albuquerque, New Mexico 
The Colorado economic impact study summarizes employment and economic benefits to the state from activities associated with the Uranium Mill Tailings Remedial Action (UMTRA) Project during Colorado state fiscal year (FY) 1993. To capture employment benefits, a questionnaire was distributed to subcontractor employees at the active UMTRA Project sites of Grand Junction, Rifle, and Gunnison, Colorado. An estimated 52 percent of the employees working on the UMTRA Project responded to this information request. Economic data were requested from each prime subcontractor, as well as from the Remedial Action Contractor. The most significant benefits associated with the UMTRA Project in Colorado are summarized below.

\section{EMPLOYMENT}

- Direct employment was estimated at $\mathbf{8 9 4}$ workers; this represents the number of workers hired for either permanent or seasonal work.

- An estimated 89 percent of all direct employment was local. Local is defined as maintaining a permanent residence within a daily commute of work.

- Secondary employment resulting from remedial action at the active Colorado UMTRA Project sites and the Grand Junction vicinity property program is estimated at 546 workers.

- Total employment (direct and secondary) is estimated at 1440 workers for the period of study (July 1, 1992, to June 30, 1993).

\section{ECONOMIC BENEFITS}

- An estimated $\$ 24.1$ million was paid in wages to UMTRA workers in Colorado during FY1993.

- Direct and secondary wage earnings were estimated at $\$ 39.9$ million.

- Income tax payments to the state of Colorado were estimated at $\$ 843,400$ during FY1993.

- The gross economic impact of UMTRA Project activities in the state of Colorado is estimated at $\$ 70$ million during the 1 -year study period.

- The net economic benefit to the state of Colorado was estimated at $\$ 57.5$ million, or $\$ 5.90$ per dollar of funding provided by Colorado. This figure includes both direct and secondary benefits but does not include the impact of alternative uses of the state funding. 


\section{OTHER BENEFITS}

- Employment on the UMTRA Project provides training opportunities that apply to other employment prospects.

- More than $\mathbf{4 0}$ cities in the stata of Colorado benefited from purchases or provided services related to the UMTRA Project.

- More than 300 subcontractors and vendors within the state of Colorado supplied services and materials to the UMTRA Project valued at more than $\$ 17$ million.

The UMTRA Project provided specific services in some communities. In Gunnison, a permanent alternate water supply system was constructed to serve residents in the Dos Rios subdivision. In addition, the UMTRA Project is restoring and enhancing wetland and riparian areas as mitigation for wetland and wildlife impacts on land administered by the U.S. Bureau of Land Management. 
TABLE OF CONTENTS

Section $\quad$ Page

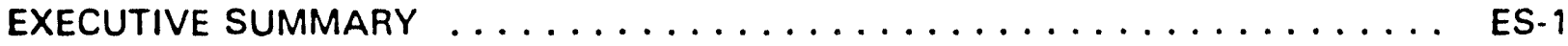

1.0 INTRODUCTION AND APPROACH $\ldots \ldots \ldots \ldots \ldots \ldots \ldots \ldots \ldots \ldots \ldots \ldots$

2.0 UMTRA PROJECT EMPLOYMENT NEEDS $\ldots \ldots \ldots \ldots \ldots \ldots \ldots \ldots \ldots \ldots \ldots$

2.1 Remedial action employment needs .................... $2-1$

2.2 Vicinity property employment needs . . . . . . . . . . . . . 2-2

2.3 Dos Rios water supply system employment needs . . . . . . . . . . . 2-2

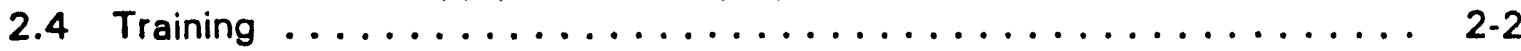

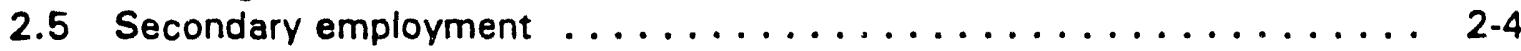

3.0 UMTRA PROJECT MATERIAL, SERVICES, AND SUPPORT $\ldots \ldots \ldots \ldots \ldots \ldots$

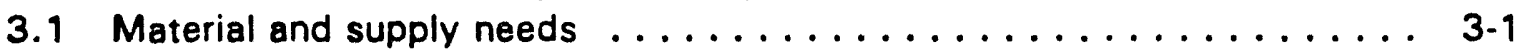

3.2 Support needs .......................... 3.1

4.0 UMTRA PROJECT EMPLOYMENT IN COLORADO IN FISCAL YEAR 1993 . . . 4 4-1

4.1 Grand Junction ............................ 4-1

4.1.1 Remedial action employment .................. 4-1

4.1.2 Vicinity property program employment ............. 4-2

4.1.3 Secondary employment .................... 4-2

4.1.4 Total employment impact ................ 4-3

4.2 Gunnison ............................ 4.3

4.2.1 Remedial action employment . . . . . . . . . . . . . 4 4-3

4.2 .2 Secondary employment ................... 4-4

4.2.3 Dos Rios water supply employment . . . . . . . . . . . . . . . 4-4

4.2.4 Total employment impact .................. 4-4

4.3 Rifle ............................ 4.5

4.3.1 Remedial action employment . . . . . . . . . . . . 4-5

4.3.2 Secondary employment ................. 4.5

4.3.3 Total employment impact . . . . . . . . . . . . . 4-5

4.4 Trends in UMTRA employment in Colorado . . . . . . . . . . . . . . . 4-6

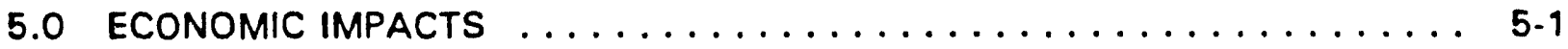

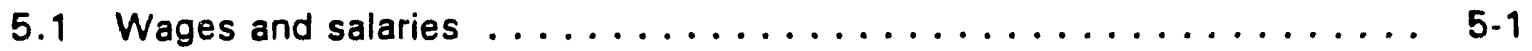

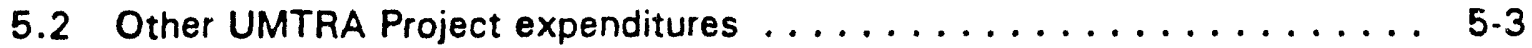

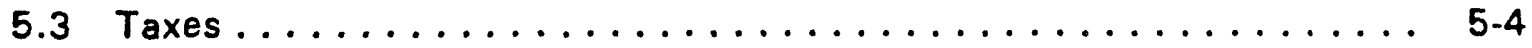

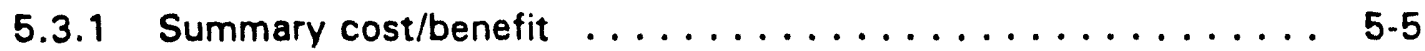

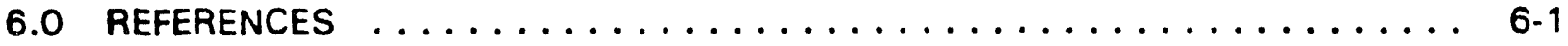

ATTACHMENT 1 WORKER QUESTIONNAIRE

ATTACHMENT 2 UMTRA PROJECT VENDORS AND SUBCONTRACTORS

ATTACHMENT 3 EMPLOYMENT AND EARNINGS MULTIPLIERS 


\section{LIST OF TABLES}

\section{Table}

Page

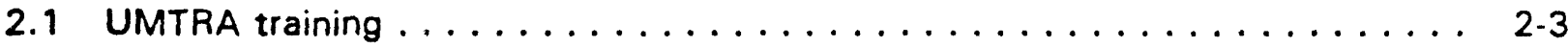

4.1 Estimated average remedial action employment at the Grand Junction UMTRA Project site, Fr1993 . . . . . . . . . . . . . . . . . . . . . . 4-2

4.2 Total estimated employment related to the Grand Junction UMTRA Project activities ............................... 4-3

4.3 Estimated average remedial action employment, Gunnison . . . . . . . . . . . . 4-4

4.4 Total estimated employment related to Gunnison UMTRA Project activities . . 4.4

4.5 Estimated employment at the Rifle UMTRA Project site . . . . . . . . . . 4-5

4.6 Total estimated employment related to Rifle UMTRA Project activities . . . . . 4-6

4.7 Total estimated UMTRA Project employment in Colorado . . . . . . . . . . . . 4-7

5.1 Wages paid at active UMTRA sites in Colorado . . . . . . . . . . . . . 5 -2

5.2 Income impact from UMTRA Project activities in Colorado, July 1, 1992 to

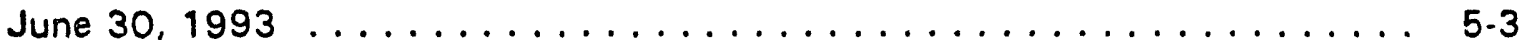

5.3 Other Project expenditures $\ldots \ldots \ldots \ldots \ldots \ldots \ldots \ldots \ldots \ldots \ldots \ldots$

5.4 Income tax payments . . . . . . . . . . . . . . . . . . . 5-4

5.5 Summary economic impacts of UMTRA Project at Colorado sites July 1, 1992

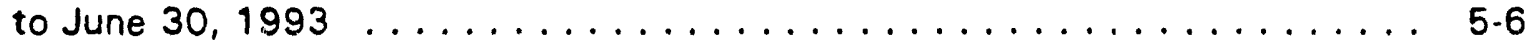

5.6 Direct and secondary income impacts from UMTRA Project activity at Colorado

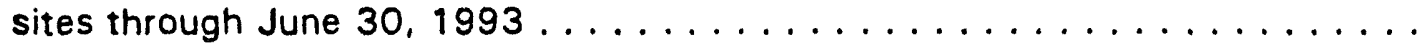




\section{LIST OF ACRONYMS}

$\begin{array}{ll}\text { Acronym } & \text { Definition } \\ \text { DOE } & \text { U.S. Department of Energy } \\ \text { FY } & \text { fiscal year } \\ \text { ICC } & \text { Industrial Constructors Corporation } \\ \mathrm{km} & \text { kilometer } \\ \mathrm{mi} & \text { mile } \\ \text { MK-F } & \text { Morrison Knudsen-Ferguson } \\ \text { RAC } & \text { Remedial Action Contractor } \\ \text { TAC } & \text { Technical Assistance Contractor } \\ \text { UMTRA } & \text { Uranium Mill Tailings Remedial Action } \\ \text { VP } & \text { vicinity property }\end{array}$




\section{CHANGE HISTORY}

\begin{tabular}{ccl}
\hline Document version & Date & \multicolumn{1}{c}{ Pages/comments } \\
\hline Ver. 1 & $11 / 9 / 93$ & Initial version. \\
\hline Ver. 2 & $11 / 12 / 93$ & $\begin{array}{l}\text { TAC review and editing } \\
\text { changes }\end{array}$ \\
\hline
\end{tabular}




\subsection{INTRODUCTION AND APPROACH}

As required by the Romer-Twining Agreement of 1990, the U.S. Department of Energy (DOE) has prepared the annual economic impact study for the state of Colorado. This report assesses the economic impacts related to the DOE Uranium Mill Tailings Remedial Action (UMTRA) Project in Colorado during the state fiscal year (FY) between July 1. 1992, and June 30, 1993. Employment, salaries and wages, and other related economic benefits are discussed, quantified, and then compared to the state's 10-percent share of the remedial action costs to estimate net economic benefit. When possible, actual data have been used to describe the situation; however, due to the complexity of the UMTRA Project and large numbers of subcontractors involved, the data were not always available and estimates were used to derive economic indicators.

This study describes the types of employment associated with the UMTRA Project and estimates of the numbers of people employed by UMTRA Project subcontractors in Colorado during the 1992-1993 state FY. Jobs are described as permanent or seasonal and in terms of benefitting local or out-of-the-area workers and communities. Secondary employment is estimated using a multiplier developed by the state of Colorado, vivision of Local Government. Finally, a comparison is made to FY1992 employment levels and to future UMTRA Project needs. Economic benefits related to the employment, salaries and wages, and purchases of supplies and materials, and other expenditures are derived from the use of actual numbers in combination with estimates and economic multipliers.

This is the second year the annual Colorado economic impact study has used actual information from field data collection to estimate employment and economic benefits. In some instances, the data base may vary slightly from 1992 because of refinements made in data collection methods for the 1993 report. These instances are noted in the text.

Most raw data necessary for this report were collected by Morrison Knudsen-Ferguson (MK-F), the Remedial Action Contractor (RAC) to the DOE. MK-F obtained information from subcontractors and provided information specific to the MK-F management of the remedial action site activities. The vicinity property (VP) program is coordinated by Rust Geotech, Inc. (Geotech), in Grand Junction, Colorado. Geotech was instrumental in providing data on the VP program employment and economic benefits. Southwest Environmental prepared the employment analysis. Jacobs Engineering Group Inc., the Technical Assistance Contractor (TAC) to the DOE, provided program-level information and prepared the economic analysis.

VPs are properties located outside a designated site boundary that have been contaminated by tailings dispersed by wind or water erosion or by removal by people before the hazards of the tailings were known. The VP program was initiated to cleanup individual residences, commercial structures, public facilities, and vacant properties. Originally, over 4000 VPs were identified for cleanup in the state of Colorado. Most of these properties are located in Grand Junction, Colorado.

MK-F requested their prime subcontractors at the Grand Junction, Gunnison, and Rifle UMTRA Project sites to complete questionnaires, in order to have site-specific information 
for preparing this study. Not all workers were available at the time the information was requested; approximately 52 percent of all workers employed during the study period completed and returned the questionnaires. The responses on the questionnaires substantiate the estimates provided by the subcontract site managers. The questionnaire is provided in Attachment 1.

This study assesses benefits associated with the Grand Junction, Gunnison, and Rifle UMTRA sites for the 1-year period under study. Remedial action at the Naturita UMTRA site is scheduled to begin in 1994. Work at the Slick Rock and Maybell sites is expected to begin in 1995. The only current economic benefits associated with the Slick Rock, Naturita, and Maybell sites are related to UMTRA Project support work (e.g., field studies). 


\subsection{UMTRA PROJECT EMPLOYMENT NEEDS}

MK-F manages each UMTRA Project site surface remedial action and oversees the activities of many subcontractors. A prime subcontractor for each site is selected through a competitive bidding process and must be approved by MK-F and the DOE. The prime subcontractors may hire other subcontractors to perform portions of their contracts. In addition, portions of the remedial action are not awarded to the prime subcontractor but are independently contracted by MK-F, who manages those contracts. The purpose of hiring many subcontractors is to distribute the economic benefits related to the UMTRA Project and to provide opportunities to small Colorado businesses. The following prime subrontractors are currently active at UMTRA sites in Colorado:

- Grand Junction site: Industrial Constructors Corporation (ICC), of Missoula, Montana.

- Gunnison site: AMES Construction, Inc. (AMES), of Burnsville, Minnesota.

- Rifle site: Green International, Inc. (Green), of Denver, Colorado.

The VP cleanup programs are managed slightly differently. The variety of site conditions present often requires more than one contractor to manage cleanup and restoration. These subcontracts typically have been awarded to small businesses in the area. Attachment 2 lists the subcontract companies used for VP cleanup in 1993. In Grand Junction, 50 companies completed cleanups on 193 properties. With 53 properties remaining, an estimated 4141 VPs were completely cleaned up as of July 1993 (Elmer, 1993). In Gunnison and Rifle, no VP properties were completed during FY1993. Site VP cleanup typically requires demolition, if buildings are present and contaminated; removal of all contaminated soils and other materials, if present; and restoration of disturbed areas.

In addition to work on the remedial actions and VPs in FY1993, significant work was completed on providing a water supply system for the residents of the Dos Rios Subdivision adjacent to the Gunnison processing site. The DOE is providing a water supply system to these residents because the groundwater they were using for drinking water was found to contain low levels of contamination related to elements leaching out of a tailings pile approximately 0.5 mile $(\mathrm{mi})[0.8$ kilometers $(\mathrm{km})]$ east of the subdivision. This tailings pile is on the Gunnison processing site. The contract to provide the water system is managed by Tierdael Construction from Denver and Southwest Contracting from Cortez, Colorado.

\subsection{REMEDIAL ACTION EMPLOYMENT NEEDS}

UMTRA Project remedial action employment needs are similar to those of large earth-moving projects; i.e., they require large numbers of truck drivers and heavy equipment operators. However, the unique needs of the UMTRA Project often require specific experience that local workers have not obtained through work in the mining or construction industries. The contaminated materials contain low levels of radioactivity; all handling and transportation activities are subject to Federal and 
state regulations. To most efficiently move these large volumes of contaminated materials, trucks with a capacity of 18 to 20 cubic yards are used. For these reasons, area workers who are experienced in driving commercial trucks or operating mining equipment generally are not qualified to immediately assume a truck driver or heavy equipment operator position at an UMTRA Project site. Onthe-job training is provided, when possible. In addition to truck drivers and equipment operators, other employment categories typically required include surveyors, mechanics, laborers, health physics monitors, and engineers. Each subcontractor generally relocates experienced managers from other office locations to supervise their contracts. Workers hired for most other job categories, such as truck drivers, laborers, mechanics, or equipment operators, are recruited from local areas. Subcontra:tors use news releases, local job service offices, company announcements, and local colleges to advertise the need for these positions. Managerial positions are generally permanent for the length of the remedial action ( 3 to 5 years). Most other positions are seasonal; that is, the duration of employment is dependent on the weather, specific UMTRA Project needs, or permit restrictions. Rifle and Gunnison experience severe winter weather and also have mandatory shutdown periods in the winter and spring for wildlife mitigation. Workers laid off in the fall are encouraged to return in the spring. Some jobs may require only a few weeks (e.g., building a fence). More typically, seasonal workers are hired for 5 to 6 months.

\subsection{VICINITY PROPERTY EMPLOYMENT NEEDS}

Employment related to the VP program typically uses skills associated with the construction, landscaping, or reclamation jobs. The duration of the subcontracts relates to the amount and type of contamination present at a site. Remediation at some sites may be completed in one week, while at others it may take months or years. In FY1993, Grand Junction VP subcontractors worked most of the year.

\subsection{DOS RIOS WATER SUPPLY SYSTEM EMPLOYMENT NEEDS}

Work activities on the water supply system required experience in excavation and trenching, pipe laying, and miscellaneous job skills related to constructing a water supply system (e.g., providing service hookups from the pipes to residences, building a water treatment plant, and installing a water tank). Most of this project was completed during the study period.

\subsection{TRAINING}

Through its contractors, the DOE provides training for all employees hired for UMTRA work. Table 2.1 lists training classes and their applicability to other similar work, particularly to superfund sites (Logan, 1993). 
Table 2.1 UMTRA training

\begin{tabular}{lc}
\hline \multicolumn{1}{c}{ Training subject } & Superfund site applicability \\
\hline ESH site indoctrination & No \\
Respiratory protection & No \\
Hazard communication & No \\
Hearing communication & No \\
Radiation worker & No \\
Occupational worker & No \\
Transportation & No \\
Fire prevention & No \\
Asbestos abatement & Yes \\
40-Hour OSHA (29 CFR 1910.120) & Yes \\
24-Hour OSHA (29 CFR 1910.120) & Yes \\
8-Hour OSHA annual refresher & Yes \\
8-Hour OSHA for supervisors & Yes \\
OSHA construction regulations course & Yes \\
CPR/first aid & Yes \\
Blood-borne pathogens & Yes \\
\hline
\end{tabular}

'Radiation training for visitors.

ESH - Environment, Safety, and Health.

OSHA - Occupational Safety and Health Administration.

Chem Waste Management Federal Environmental Services (Chem Waste Management) provides radiation monitoring training for inexperienced workers. An inexperienced worker is paired with an experienced individual to learn on-site work skills, provided in-class training, and tested. The training takes approximately six months to complete. At the end of the remedial action, these workers generally find other work opportunities at national laboratories or Superfund sites (Couch, 1993).

In general, employee health, safety, and technical training are provided at the work site. Weekly safety meetings are mandatory for all workers. In addition to formal training, on-the-job training is conducted. An individual with some experience in operating heavy equipment may not have the necessary experience to immediately begin working with the contaminated materials or on the specific construction 
equipment in use at the site. Through on-site, progressively increasing experience, an individual may acquire the skills required to assume greater project responsibility and to enhance employment potential on other projects.

\subsection{SECONDARY EMPLOYMENT}

In addition to employment directly related to the UMTRA site or VP remediations, secondary employment occurs as a result of direct employment as a project brings increased money into an economy and the increased demand for workers supports the new purchases. Secondary employment typically occurs primarily in the services sector. Due to the long-term impact of the VP program in Grand Junction, and large remedial action work force, it is assumed that secondary employment has occurred in Grand Junction. It is likely that some secondary employment is occurring in Gunnison and Rifle. The Colorado Division of Local Affairs suggests the use of 1.5 as a multiplier to determine secondary employment related to the UMTRA Project (Larson, 1993). However, because of the unique nature of the UMTRA Project, the secondary employment reported in the following sections should be viewed with caution. The largely seasonal nature of most UMTRA work suggests that applying the multiplier to all reported jobs for the Gunnison and Rifle sites may result in higher levels of secondary employment than actually occur. 


\subsection{UMTRA PROJECT MATERIAL, SERVICES, AND SUPPORT}

\subsection{MATERIAL AND SUPPLY NEEDS}

As previously described, the UMTRA Project site remediations require work activities that would be considered similar to those used on large earth-moving operations. Typically, supplies, materials, and services are those that would be associated with a large earth-moving project. When they are available and costeffective, they are purchased locally. These purchases include fuel and oil for equipment, fencing materials, building supplies, laboratory analysis, equipment repair, miscellanecus office supplies, hardware and equipment parts, incidental office supplies, land appraisals, and training. The supplies and materials associated with VP reinediations typically include building or construction materials.

Purchasing supplies and materials locally is an UMTRA Project priority. If materials arid supplies are not available locally, or if it is not cost-effective to purchase tham locally, the region and state are evaluated for possible vendors before out-of-state purchases are mide. Attachment 2 provides a partial list of vendors and subcontractors used for material, supplies, and service for the UMTRA Project and the city in which they are located. This list is not intended to be complete, but to indicate the extent to which the UMTRA Project benefits businesses in communities throughout the state. As shown in the attachment, materials and supply purchases benefit communities of all sizes within the state of Colorado, including the Denver metropolitan area.

\subsection{SUPPORT NEEDS}

In addition to direct services, material and supply purchases, and employment directly related to remedial action activities, other activities and purchases occur in Colorado in support of the UMTRA Project. For example, before a disposal site is identified, various field studies must be completed to evaluate the appropriateness of the proposed site (or sites) and to comply with Federal and state regulations. These field studies and related laboratory tests usually are contracted to Colorado companies and may include contracts for laboratory analysis of water samples, field surveys in potentially disturbed areas for cultural and similar resources. Also, supplies may be purchased in the field. Other support activities are more general, and may include attending meetings with local planning commissioners to ensure that all necessary permits and local requirements are met. Each of these activities results in purchases and local expenditures (e.g., meals and motels) for nonlocal field personnel. 


\subsection{UMTRA PROJECT EMPLOYMENT IN COLORADO IN FISCAL YEAR 1993}

UMTRA Project-related employment in Colorado from July 1, 1992, to June 30, 1993, resulted in an estimated 894 direct and 546 secondary jobs of all kinds. Because of the seasonal nature of remedial action and the lengthy winter shutdown periods, interpreting the numbers of jobs attributed to the UMTRA Project as full-time employment would be misleading. This study only identifies the number of jobs created for FY1993.

Approximately 794 (89 percent) of the direct jobs were filled by area or local residents. These results are based on the following assumptions:

- Workers from local areas are defined as those workers who commute on a daily basis to the work site from area communities. Generally, "local" includes towns within a $60-\mathrm{mi}(96-\mathrm{km})$ radius of the processing site. In rural, western states, workers generally are willing to travel longer distances for a job than would be true in more densely populated areas.

- "Permanent employment" refers to employment lasting the duration of the remedial action ( 3 to 5 years). Although many workers are rehired after the winter shutdown, these workers would not be considered permanent. Permanent workers are typically site managers, engineers, and some radiation monitoring staff.

- "Seasonal" or "temporary employment" refers to employment that is tied to the construction season, or that may be tied to specific short-term tasks, such as installing a fence.

- The number of jobs is reported regardless of the length of the job. Using the actual numbers of workers employed by UMTRA Project subcontractors provides a useful assessment of UMTRA-related employment. Workers who have an opportunity for work that was not previously available and who are provided training are better able to find permanent employment than the long-term unemployed.

\subsection{GRAND JUNCTION}

\subsubsection{Remedial action employment}

The remedial action contract was awarded to ICC in March 1989. Work at the site shut down December 1, 1992, and started again March 1, 1993. During FY1993, the main activity consisted of transporting the contaminated materials by train and truck from the processing site to the Cheney disposal site. This activity required large numbers of truck drivers and heavy equipment operators. The transportation phase was finished in August 1993. The remedial action is expected to be complete by June 1994. Although most of the work force were not available to answer the questionnaire, worker characteristics (local versus nonlocal) are expected to be similar to those identified in the FY1992 study (DOE, 1993). It is estimated that about 90 percent of all workers were from the Grand Junction area. Table 4.1 shows the number of employees working in FY1993 for each of the 
major subcontractors at the Grand Junction site. Compared to the total number of workers employed on the remedial action in FY1992 (360 persons), the FY1993 levels are lower, as expected, because of the general winding down of the project.

Table 4.1 Estimated average remedial action employment at the Grand Junction UMTRA Project site, FY1993

\begin{tabular}{lrr}
\hline \multicolumn{1}{c}{ Contractor } & FY1992 & FY1993 \\
\hline MK-F & 22 & 24 \\
ICC $^{\mathrm{a}}$ & 261 & 175 \\
Denver and Rio Grande Western Railroad & 6 & 6 \\
Chem Waste Management & 71 & 84 \\
Total & 360 & 289 \\
\hline
\end{tabular}

- Totals for ICC include their major subcontractors.

\subsubsection{Vicinity propenty program employment}

In addition to employment related to the remedial action in Grand Junction, the vicinity property program, which is also nearing completion, has significantly affected employment. This employment is considered as full time because work on the VP program generally is not subject to weather restrictions. The direct employment related to program management was 172 jobs and indirect employment was 118 jobs. In this case, indirect employment includes office support and overhead. Subcontractor employees are estimated at 185 . The direct and indirect Geotech employment was comprised of all local workers (Elmer, 1993). Because all subcontractors were from the Grand Junction area, they are assumed to be local, as well. The total number of direct jobs related to the VP program is 357 . As anticipated, there were slightly fewer jobs in FY1993 than in FY1992 when total VP employment was estimated at 423 , or 66 fewer jobs.

\subsubsection{Secondary employment}

Using the 1.5 multiplier suggested for determining secondary employment (Section $2.5)$ results in an additional 145 jobs generated by the remedial action and 179 jobs related to the VP program. Including the indirect jobs (118) associated with overhead support to Geotech results in a total secondary employment of 442 jobs. 


\subsubsection{Total employment impact}

Table 4.2 summarizes the average total estimated employment related to Grand Junction remedial action and the VP program. Compared to FY1992, there were 165 fewer jobs in Grand Junction related to the UMTRA Project. Although the transportation phase ended in August 1993, the local Job Service Office did not report changes in the number of applicants. The large work force in Mesa County (greater than 40,000 workers) also suggests that the decreasing UMTRA employment levels represent less than a 1 -percent change in employment.

Table 4.2 Total estimated employment related to the Grand Junction UMTRA Project activities

\begin{tabular}{lc}
\hline \multicolumn{1}{c}{ Direct employment } & FY1593 \\
\hline Remedial action direct employment & 289 \\
Geotech direct employment & 172 \\
VP subcontracts direct employment & 185 \\
\hline Total direct employment & 646 \\
\hline \multicolumn{1}{c}{ Secondary employment } & 145 \\
\hline Remedial action secondary employment & 118 \\
VP indirect employment & 179 \\
VP secondary employment & 442 \\
Total secondary employment & 1088 \\
Total all employment & \\
\hline
\end{tabular}

\subsection{GUNNISON}

\subsubsection{Remedial action employment}

The remedial action contract for Gunnison was awarded to AMES in June 1992. The major work effort during FY1993 included site preparation and activities needed to prepare for hauling the tailings. The Project shut down the end of October 1992 and started up early April 1993. Table 4.3 summarizes employment at the Gunnison site. In FY1992, only 17 workers were employed at the Gunnison site, as remedial action was just beginning. Employment is expected to increase in 1994 as tailings continue to be transported to the disposal site. An estimated 62 percent of the FY93 work force was from the local area. As employment increases in 1994, it is expected most of the new jobs will be filled locally. Although work continued on the airport VP, the site is not complete and only small numbers of workers were used for short periods of time. 
Table 4.3 Estimated average remedial action employment, Gunnison

\begin{tabular}{lcc}
\hline \multicolumn{1}{c}{ Subcontractor } & FY1993 & FY1992 \\
\hline MK-F & 18 & 7 \\
AMES & 30 & 7 \\
Chem Waste & 28 & 3 \\
Management & & \\
Total & 76 & 17 \\
\hline
\end{tabular}

\subsubsection{Secondary emplorment}

In addition to direct employment, secondary employment may be occurring in Gunnison. Applying the 1.5 secondary employment multiplier to the 76 direct jobs results in an additional 38 jobs generated by the UMTRA Project.

\subsubsection{Dos Rios water supply employment}

In addition to the remedial action, construction began on the Dos Rios water supply system in FY1992. Most of the work will be completed by December 1993, with the system fully operational by the end of 1994. It is estimated that approximately 40 workers were employed in pipeline, water tank, and water treatment plant construction. Most of these workers were hired locally. Due to the short-term nature of this project it is unlikely that secondary employment was generated.

\subsubsection{Total employment impact}

Table 4.4 shows the estimated total direct and secondary employment related to the UMTRA Project activities in Gunnison.

Table 4.4 Total estimated employment related to Gunnison UMTRA Project activities

Remedial action secondary employment

Dos Rios water supply system

40

Total

$\frac{40}{154}$




\subsection{RIFLE}

\subsubsection{Remedial action employment}

The remedial action contract was awarded to Green International in April 1992. During FY1993, excavation and preparation of the Estes Gulch disposal cell was completed and the haul phase began. Site activity shut down for the winter by mid-November 1992, and start up began in mid-April 1993. No work on vicinity properties occurred until July 1993.

The average work force during the summer construction season was 132 , with a peak of 163 as tailings hauling began. Most of the workers (an estimated 82 percent) are from the local area. Table 4.5 summarizes employment at the Rifle site by major company. In FY1992, a total of 45 workers were employed in remedial action activities, reflecting the lower levels of employment during start-up. It is estimated that work force levels will increase in 1994 with the continuation of the haul phase.

Table 4.5 Estimated employment at the Rifle UMTRA Project site

\begin{tabular}{|c|c|c|}
\hline Company & FY1993 & FY 1992 \\
\hline$M K-F$ & 23 & 11 \\
\hline Green & 37 & 28 \\
\hline Nordic & 25 & - \\
\hline Chem Waste Management & 47 & 6 \\
\hline Total & 132 & 45 \\
\hline
\end{tabular}

\subsubsection{Secondary employment}

In addition to direct employment, some secondary employment is expected to be occurring. Applying the 1.5 multiplier to 132 results in an estimated 66 additional jobs.

\subsubsection{Total employment impact}

Table 4.6 summarizes the total employment associated with the Rifle UMTRA site in FY1993. These levels $:$ ie expected to increase in FY1994 because of work on VPs and the need for more truck drivers to complete the transportation phase. A total of 198 jobs related to work on the UMTRA Project in Rifle are estimated for FY1993. 
Table 4.6 Total estimated employment related to Rifle UMTRA Project activities

\begin{tabular}{lc}
\hline \multicolumn{1}{c}{ Employment } & FY1993 \\
\hline Remedial action direct employment & 132 \\
Remedial action secondary employment & 66 \\
Total & 198 \\
\hline
\end{tabular}

\subsection{TRENDS IN UMTRA EMPLOYMENT IN COLORADO}

Table 4.7 summarizes direct and secondary employment that occurred during FY1993 in Colorado. In spite of work winding down at the Grand Junction site in FY1993, the increases in work at the Gunnison and Rifle sites resulted in a net increase of 125 workers. With remedial action starts at the Naturita site in Colorado in FY1994, employment levels should remain similar to those in FY1993.

Concern has been expressed regarding an anticipated drop in employment in Grand Junction with the completion of both the VP program and remedial action. Geotech has been successfully reassigning their staff. By the end of September 1993, for example, the number of direct jobs had decreased to 72 (down from a peak of 177 in March 1993) and all but 13 employees were reassigned to other projects in Grand Junction. Geotech has an aggressive program to assist workers laid off the UMTRA Project as work is completed (Elmer, 1993). Additionally, construction in western Colorado has picked up over the past vear because of a large influx of people moving to the western slope communities of Grand Junction, Montrose, Telluride, and other area communities from California, Texas, and Arizona. Because skilled construction workers are in limited supply, it is believed that for the next year, there will be other employment possibilities that were not available a few years ago. ICC is attempting to place its workers in other ICC projects, which may mean relocation. Finally, the Chem Waste Management employees trained in radiation monitoring are also finding other employment, although they are sometimes required to relocate to other Colorado communities or to other states. 
COLORADO ECONOMIC IMPACT STUDY ON THE URANIUM MILL

Table 4.7 Total estimated UMTRA Project employment in Colorado

\begin{tabular}{lcr}
\hline \multicolumn{1}{c}{ Direct employment } & FY1993 & FY1992 \\
\hline Grand Junction remedial action & 289 & 360 \\
Grand Junction VP program & 357 & 423 \\
Gunnison remedial action & 76 & 17 \\
Dos Rios water supply system & 40 & - \\
Rifle remedial action & 132 & 45 \\
Total & 894 & 845 \\
\hline \multicolumn{1}{c}{ Secondary employment } & & \\
\hline Grand Junction remedial action-related & 145 & 216 \\
Grand Junction VP program-related & 297 & 254 \\
Gunnison remedial action-related & 38 & $\mathrm{a}$ \\
Rifle remedial action-related & 66 & 470 \\
Total & 546 & 1315 \\
\hline Total all employment & 1440 & \\
\hline
\end{tabular}

- No secondary employment was estimated in FY1992 because the small number employed during start-up would likely not have generated additional jobs. 


\subsection{ECONOMIC IMPACTS}

Generally, economic benefits accrue from direct UMTRA Project employment, purchase of goods and services to support UMTRA Project activities, and the recirculation of monies by the Project and workers. In addition, monies are returned to the state and local economies in increased tax revenues that include income, property, sales, and use taxes. Economic benefits discussed in this section include employee wages and salaries, subcontract monies, purchase of goods and services to support UMTRA Project activities (vendor information), income taxes paid by UMTRA Project workers in Colorado, and sales tax payments from materials purchased to support remedial action. Where data were unavailable, estimates are provided and the basis for the estimates are outlined.

\subsection{WAGES AND SALARIES}

Total direct wages paid to personnel working on the UMTRA Project in Colorado were estimated at about $\$ 24$ million during the study period. Total wages for direct employment at the three remedial action sites were an estimated $\$ 11$ million. Table 5.1 shows the total wages paid at each of the three sites and Grand Junction VPs. Wages shown in the table are those paid by the RAC, MK-F, Geotech, and the prime subcontractors at each site. It Joes not include wages paid to lower-tier subcontractors (i.e., contractors employed by the prime subcontractor). Wages paid were fairly evenly distributed among the three Colorado UMTRA Project sites, corisistent with the activity level at each site. The table also shows wages paid during the previous study period. In the FY1992 study period, remedial action was in a start-up phase at the Rifle and Gunnison sites and wages were paid at those sites for only a few months. Wages paid during the current study period reflect a full construction season $(7$ to 10 months). While the VP program still represented the largest single source of wages for the UMTRA program in Colorado, its portion of total wages paid was 54 percent in FY 1993 compared to 68 percent in the previous year. Remedial action at Grand Junction represents 40 percent of wages paid at UMTRA sites in Colorado, down from 85 percent in FY1992. Again, this reflects the higher level of activity at the Rifle and Gunnison sites during the current period, and the beginning of a wind-down in the activities at Grand Junction.

Direct UMTRA-related wages associated with the Grand Junction VP program totaled an estimated $\$ 13.1$ million and includes prime contractor personnel (field personnel, construction supervision, clerical support) and wages paid to subcontract employees. The estimated $\$ 24$ million paid in wages and salaries during the study period represents only wages directly attributable to UMTRA Project activities in Colorado.

Secondary labor income results from the direct labor income. This secondary labor income includes indirect income generated by UMTRA Project expenditures for materials, equipment, and supplies and induced income that results from 
Table 5.1 Wages paid at active UMTRA sites in Colorado

\begin{tabular}{|c|c|c|}
\hline \multirow[b]{2}{*}{ Site } & \multicolumn{2}{|c|}{ Total wages paid in $\$^{\circ}$} \\
\hline & FY1993 & FY 1992 \\
\hline Rifle & $3,718,600$ & 726,900 \\
\hline Gunnison & $2,876,400$ & 239,000 \\
\hline Grand Junction & $4,389,500$ & $5,614,000$ \\
\hline Total & $\$ 10,984,500$ & $\$ 6,580,500$ \\
\hline Grand Junction VPs ${ }^{b}$ & $\$ 13,092,000$ & $\$ 13,652,800$ \\
\hline Grand total & $\$ 24,076,500$ & $\$ 20,233,300$ \\
\hline
\end{tabular}

- Payroll information is based on data supplied by site contractors.

bTotal includes about $\$ 7.9$ million in labor costs for Geotech VP prime subcontractors.

Note: Numbers recorded to the nearest $\$ 100$.

employment created by respending direct and indirect labor income within the state. While the direct labor income provides economic benefits through the generation of secondary income, not all the direct income remains within the state. Some contractor personnel reside outside the state and a portion of their income probably will return to their states of permanent residence. This would be particularly true of workers who do not bring their families or the workers who remain in the state only during the construction season.

Secondary (indirect and induced) earnings are estimated using multipliers that represent the additional income earned for each direct dollar. Multipliers used in this study are provided by the Colorado Division of Local Government, which has updated and revised multipliers for this year's economic impact study (see Attachment 3). The earnings multipliers used represent the average industry multiplier for the applicable region in Colorado. For example, an earnings multiplier of 1.669 was applied to direct income earnings at the Grand Junction and Rifle sites. This represents an average of the three industry sector multipliers shown in Attachment 3 in the energy and mining region of the state. For the Gunnison site, an earnings multiplier of $\mathbf{1 . 5 5 8}$ is the average industry multiplier for the ski country region, and that was applied to the direct income to estimate secondary earnings. Table $\mathbf{5 . 2}$ shows estimated direct and secondary earnings at the UMTRA sites in Colorado.

As shown in Table 5.2, a total of $\$ 15.8$ million was estimated in secondary earnings from UMTRA Project activities at the remedial action sites and Grand Junction VPs. Direct and secondary income totaled $\$ 39.9$ million during the study period. This is $\$ 7.8$ million higher than FY1992, when an estimated $\$ 32.1$ million was generated in direct and secondary wage income. 
Table 5.2 Income impact from UMTRA Project activities in Colorado, July 1, 1992 to June 30, 1993

\begin{tabular}{lcccc}
\hline & \multicolumn{3}{c}{ Thousands of dollars } \\
\cline { 2 - 4 } \multicolumn{1}{c}{ Site } & $\begin{array}{c}\text { Direct } \\
\text { earnings }\end{array}$ & $\begin{array}{c}\text { Secondary } \\
\text { earnings }\end{array}$ & Total earnings \\
\hline Rifle & 3,719 & 2,488 & 6,207 \\
Gunnison & 2,876 & 1,605 & 4,481 \\
Grand Junction site & 4,390 & & 2,937 & 7,327 \\
Grand Junction VPs & 13,092 & & 8,759 & 21,851 \\
Total & 24,077 & & 15,789 & \\
\hline
\end{tabular}

Note: Secondary multipliers used were based on the average earnings multiplier applicable to the site areas provided by the Colorado Division of Local Government.

\subsection{OTHER UMTRA PROJECT EXPENDITURES}

Other expenditures include UMTRA Project resource requirements and linkages that are key to deterrnining the level of secondary effects. Linkages are other businesses within the community that provice resource requirements. The local linkages benefit from UMTRA Project purchases and services. Secondary effects occur when linkages respend these dollars in the community. The level of impact depends on the availability of the businesses required and the extent to which the Project uses them.

Obtaining primary resources from the local communities is preferable. Purchasing construction materials in bulk from local communities is preferred, because of lower transportation costs. If the needed materials are not available locally, purchases are diverted to the nearest available source.

An estimated $\$ 17.2$ million was provided for other subcontract (lower tier) and vendor expenditures within Colorado during the study period. These expenditures include the purchase of supplies and materials, dislocation monies, subcontracts, equipment rental, and the like. The $\$ 17.2$ million includes only subcontractor and vendor expenditures by Geotech and MK-F for companies located within Colorado. Because Green International, prime subcontractor at the Rifle site, is a Colorado company, payments to them are included in the total estimate. However, payments to ICC and AMES, prime subcontractors at the Grand Junction and Gunnison sites, are not included because these firms are located outside of Colorado. It is likely that these companies return a portion of their payments to the state economy through purchase of materials and supplies from Colorado companies. Lower-tier subcontractor and vendor expenditures represent most of the estimated $\$ 28.5$ million in other UMTRA Project expenditures within the state 
of Colorado during the study period. Table 5.3 breaks down these categories and estimated expenditures. Other expenditures include administrative and office overhead costs, DOE and TAC expenditures for Project-related travel to Colorado, and monies to Colorado firms that performed special studies or analyses (e.g., cultural resource surveys and water sampling analyses) to meet UMTRA Projecr requirements during the study period.

Table 5.3 Other Project expenditures

\begin{tabular}{lc}
\hline \multicolumn{1}{c}{ Category } & Expenditures \\
\hline Subcontractor/vendor & $\$ 17,213,400$ \\
Administrative/office overhead & $10,127,900$ \\
Travel costs (motels, meals, auto rental) & 95,950 \\
Special study/analyses & $1,035,200$ \\
Total & $\$ 28,472,450$ \\
\hline
\end{tabular}

\subsection{TAXES}

In addition to the direct UMTRA Project expenditures discussed above, the Project provides economic income to the state through payment of taxes. The primary tax source to the state from the UMTRA Project is income tax payments. During the study period, an estimated $\$ 3.7$ million was paid in state and Federal income taxes. Of this, $\$ 843,400$ was state of Colorado income tax. Table 5.4 shows the income tax payments per site during the study period. Income tax payments shown in Table 5.4 are based on wages paid for direct labor. The data shown in the table include income tax payments made by Geotech and MK-F and estimates of payments made by the prime subcontractors. Estimated income tax payments are slightly higher than FY1992 when $\$ 3.1$ million was paid, $\$ 686,800$ of which was state income tax payments.

Table 5.4 Income tax payments

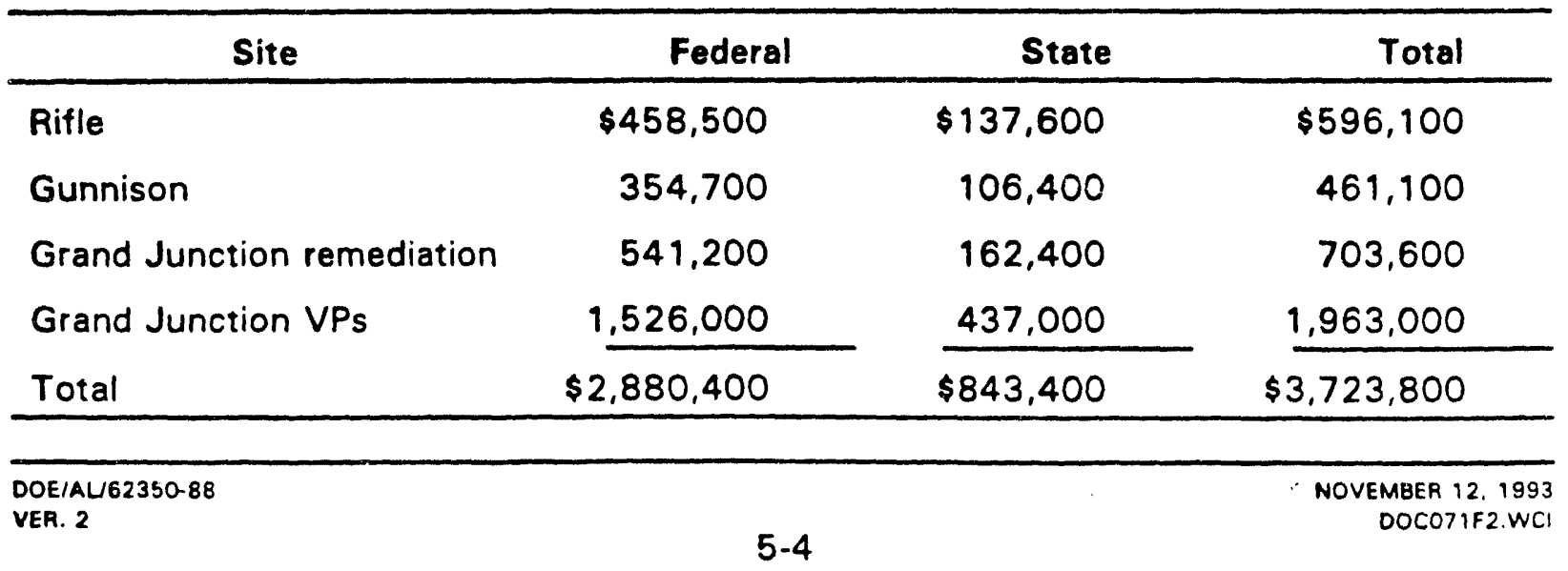


Applying the same multipliers used to project secondary income impacts (i.e., wages generated by secondary employment) to the income tax withholdings results in an additional $\$ 552,324$ in income tax payments to the state of Colorado. This is a total $\$ 1.4$ million in estimated income tax payments to the state from wages paid for direct and secondary employment.

The type and extent of investment in UMTRA Project facilities is a factor in determining the local public sector revenues generated by the Project. The level and nature of investment refers to the degree to which land purchases or development (i.e., office buildings, and the like) are required. This type of investment is subject to local property taxes. The degree to which this investment occurs determines the amount of local public revenues generated. Unlike other development projects, the UMTRA Project will not acquire or develop any land in the communities that would otherwise be subject to local property taxes. However, remediation may affect the potential future land use of land being remediated and may increase future public revenues generated from the redeveloped land.

A number of other tax sources result (directly and indirectly) from UMTRA Project activities, providing income to state and local governments. Sales taxes generated by the purchase of goods and materials for the Project, as well as by recirculation of monies through the local, regional, and state economies, represent a source of revenue to state and local governments. In Colorado, a 3-percent sales tax is applied to all material purchases. An estimated $\$ 342,000$ was paid to the state in sales taxes on materials purchased for the UMTRA Project (this amount was estimated from data provided by Geotech and calculated from subcontractor/vendor information provided by MK-Fl. Some local governments also assess sales taxes. For example, $\$ 1,256$ in sales taxes were paid by the remedial action subcontractor at the Grand Junction site. Use taxes, such as fuel and tobacco taxes, are also returned to state and local governments. Travel to the Colorado sites by the DOE and other UMTRA contractors not located or working directly at the site also generates tax income (e.g., motel and lodging taxes).

\subsubsection{Summary cost/benefit}

The gross economic impact of UMTRA Project activities in Colorado is estimated at $\$ 70$ million during the 1 -year study period (Table 5.5). The state funding requirement during the period (10 percent of the remedial action costs) was $\$ 9.7$ million. The net economic benefit to the state of Colorado was about $\$ 57.5$ million, or about $\$ 5.90$ per dollar of funding provided by Colorado. This perdollar estimate includes both direct and secondary benefits but does not take into account the impact of alternative use of the state funding (income that would have been generated had the state's $\$ 9.7$ million share been used for other purposes). The gross economic impact considering only direct sources totals $\$ 53$ million. Accounting for the state's $\$ 9.7$ million funding, the direct net benefit is estimated at $\$ 40.8$ million, or about $\$ 4.20$ per dollar of funding. 
Table 5.5 Summary economic impacts of UMTRA Project at Colorado sites July 1, 1992 to June 30,1993

\begin{tabular}{lccc}
\hline \multicolumn{1}{c}{ Category } & Direct & Secondary & \multicolumn{1}{c}{ Total } \\
\hline Labor income & $\$ 24,077$ & $\$ 15,789$ & $\$ 39,866$ \\
Other expenditures & 28,472 & $342^{\circ}$ & 28,814 \\
Colorado income tax & 843 & 552 & $-1,395$ \\
Total gross economic impact ${ }^{b}$ & 53,392 & 16,683 & 70,075 \\
Colorado funding requirement & $-9,700$ & & $-9,700$ \\
Federal income tax & $-2,880$ & & $-2,880$ \\
Net economic benefit & $\$ 40,812$ & & $\$ 57,495$ \\
\hline
\end{tabular}

- Secondary impacts represent the estimated sales tax paid on material purchases.

b Federal income tax payments were excluded because these payments do not accrue benefit to the state.

This study focuses on UMTRA-related economic impacts to the state of Colorado for a 1-year period. Data used were based on actual expenditures reported by contractors at each active site. Previous studies have estimated impacts for the duration of remedial activities in Colorado, including projections of future activities. Table 5.6 shows the income impacts reported for previous years, plus results from the current study. Total income impacts (direct and secondary) are estimated at $\$ 237.4$ million through June 1993. Labor income from the UMTRA Project was estimated to average $\$ 37.5$ million annually over the life of the Project (DOE, 1992). The estimated $\$ 39.9$ million (Table 5.5) for the FY1993 period is higher than the projected average. 
Table 5.6 Direct and secondary income impacts from UMTRA Project activity at Colorado sites through June 30, 1993

\begin{tabular}{|c|c|c|c|}
\hline \multirow[b]{2}{*}{ Site } & \multicolumn{3}{|c|}{ Thousands of dollars } \\
\hline & $\begin{array}{c}\text { Cumulative } \\
\text { through June } \\
1992\end{array}$ & 1993 & Total \\
\hline Durango & 26,278 & 0 & 26,278 \\
\hline Grand Junction & 164,981 & 29,178 & 194,159 \\
\hline Gunnison & 404 & 4,481 & 4,885 \\
\hline Rifle & 5,918 & 6,207 & 12,125 \\
\hline Total & 197,581 & 39,866 & 237,447 \\
\hline
\end{tabular}




\subsection{REFERENCES}

Couch, Ernie, 1993. Chem Waste Management, Federal Environmental Services, Albuquerque, New Mexico, personal communication with Sandra Beranich, Southwest Environmental, Albuquerque, New Mexico, October 26, 1993.

DOE (U.S. Department of Energy), 1993. Final Colorado Economic Impact Study on the Uranium Mill Tailings Remedial Action (UMTRA) Project, Colorado State Fiscal Year 1992, UMTRA-DOE/AL-400691.0000, DOE UMTRA Project Office, Albuquerque Operations Office, Albuquerque, New Mexico.

DOE (U.S. Department of Energy), 1992. Colorado Economic Impact Study for the Uranium Mill Tailings Remedial Action (UMTRA) Project, Colorado State Fiscal Year 1991, UMTRA-DOE/AL-400676.0000, DOE UMTRA Project Office, Albuquerque Operations Office, Albuquerque, New Mexico.

Elmer, John, 1993. Chem-Nuclear Geotech, Grand Junction, Colorado, personal communication to Sandra Beranich, Southwest Environmental, Albuquerque, New Mexico, October 25-26, 1993.

Larson, Dave, 1993. Colorado Division of Local Affairs, Denver, Colorado, personal communication to Sandra Beranich, Southwest Environmental, Albuquerque, New Mexico, October 28, 1993.

Logan, Vern, 1993. Morrison Knudsen-Ferguson, Albuquerque, New Mexico, personal communication to Sandra Beranich, Southwest Environmental, Albuquerque, New Mexico, October 11 and 25, 1993. 
ATTACHMENT 1

WORKER QUESTIONNAIRE 


\section{GRAND JUNCTION UMTRA PROJECT EMPLOYEE QUESTIONNAIRE'}

NAME:

DATE:

1) To what city and state do you claim permanent residency? City State

2) If you moved to Grand Junction for work on the UMTRA Project, please estimate the month and year of arrival. Month Year

3) How did you find out about the Uranium Mill Tailings Remedial Action (UMTRA)

Project in Grand Junction, Colorado?

Grand Junction newspaper advertisement Company announcement Other newspaper advertisement Other (please specify)

4) Have you worked on other UMTRA Projects? If yes, please list locations.

- Yes (locations) No

5) When did you begin work on the UMTRA Project in Grand Junction, Colorado? Month Year

6) What is your job title? (for example, site engineer, laborer, equipment operator)

7) What is your employee status?

_ Permanent _ Seasonal

8) Did you bring family members or spouse with you? If yes, how many?

$$
\text { _ Yes _ No _ Children__ Adults }
$$

9) Did you have difficulty locating housing?

$$
\text { - Yes - No }
$$

10) Where are you currently residing? (for example, Grand Junction, Fruita, and so on)

$$
\text { City }
$$
State

\footnotetext{
'Identical questionnaires were sent to each site; only the site name was changed on each set of questionnaires. 
GRAND JUNCTION UMTRA PROJECT EMPLOYEE QUESTIONNAIRE (continued)

11) What type of residence are you living in? Do you rent or own the residence?

- Apartment _ House

- Mobile Home_Other (specify)

12) Are you sharing your residence with other UMTRA workers? If yes, how many?

_ Yes _ No (number of roommates/housemates) _

13) Hew many miles do you drive to work?

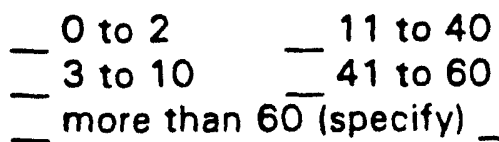


ATTACHMENT 2

REPRESENTATIVE UMTRA PROJECT VENDORS AND SUBCONTRACTORS 


\section{TABLE OF CONTENTS}

\section{Title}

Colorado Vendors Used for Morrison Knudsen-Ferguson and Chem Waste Management Federal Environmental Systems

Common Colorado Vendors Used by UMTRA Vicinity Property Subcontractors

Colorado Subcontractors Used for the Grand Junction Vicinity Property Program 


\section{COLORADO VENDORS USED BY MORRISON KNUDSEN-FERGUSON AND CHEM WASTE MANAGEMENT FEDERAL ENVIRONMENTAL SYSTEMS}

\section{Vendor}

5th Street Photo and Music

\section{ACS}

Action Shop Services

Ahkeah Construction

Air \& Water Technologies

Albert \& Karen O'Toole

Allied Carriers Exchange

Alpine Express, Inc.

Alpine Moving \& Storage

American Indian Science

American Red Cross

American Propane Service

Arrow Gas Company

Audio Visual Ventures

A-1 Body Shop

B \& B Appraisal

Barbara Hayes

Bess Investments

Bestway Sewer Service

BFI

Bill Burke

Bill Hutton

Blue Mesa Lumber, Co.

Brookhart's

Brookhart's Inc.

Buck Stove Works

Bud Franz

Business Machine Service

Carol Terrell

CASFM c/o Love \& Associates

CDS Laboratories

Cecil's Welding

Chelewski Pipe \& Supply

Chen Northern Inc.

Citizens for Recycling

City Market

City of Grand Jurn.tion

City of Gunnison

City of Gunnison - Elec

City of Rifle

Clerk of the Water Clerk

Colorado State University

Coast to Coast
Location

Rifle, CO

Grand Junction, CO

Rifle, CO

Cortez, CO

Gunnison, $\mathrm{CO}$

Rifle, CO

Denver, $\mathrm{CO}$

Gunnison, CO

Gunnison, CO

Boulder, CO

Gunnison, CO

Grand Junction, CO

Grand Junction, CO

Clifton, CO

Gunnison, $\mathrm{CO}$

Grand Junction, CO

Grand Junction, CO

Grand Junction, CO

Grand Junction, CO

Glenwood Springs, CO

Grand Junction, CO

Rifle, CO

Gunnison, CO

Rifle, CO

Grand Junction, CO

Grand Junction, CO

Grand Junction, $C O$

Grand Junction, CO

Rifle, $\mathrm{CO}$

Boulder, CO

Durango, CO

Tomichi, CO

Rifle, CO

Glenwood Springs, CO

Grand Junction, CO

Gunnison, CO

Grand Junction, CO

Gunnison, CO

Gunnison, CO

Rifle, CO

Montrose, CO

Fort Collins, CO

Grand Junction, CO 


\section{Vendor}

Colorado Analytical Lab

Colorado Department of Health

Colorado Department of Revenue

Colorado, Department of Transportation

Colorado Handyman

Colorado Mountain College

Colorado Mountain Water

Colorado Office Products

Colorado Recreation Equipment

Colorado Scale Center

Colorado Silica Sand

Colorado Water Court

Colorado West Fire Extinguishing

Complete Archaeological Service

Compliance Publishers

Computer Shopper

Conestoga Storage

Con-Sy, Inc.

CRMCA

Crested Butte Communications

Custom Typewriter Service

$D \& G$ Fencing $\mathrm{Co}$.

Daily Sentinal

Dana Helvey-Pennington Studio

Deep Rock

Deep Rock

Dennis Steckle Realtors

Depot Avionics

Dr. Perry L. Rashleigh, MD.

Durango Office Products

Electrical Dynamics

Energy Equipment \& Supply

Ernst Engineering Co.

Family Fair

Flairmont Furniture

Four Corners Welding and Gas

Four States Tire

Fullmer's True Value Hardware

Gag Pocket Flight Guide

Garfield County School

Gear's, Inc.

Gene Hollenbeck

Glenwood Post

Glenwood Septic Tank

Golden Sottware, Inc.
Location

Brighton, $\mathrm{CO}$

Denver, CO

Denver, $C O$

Durango, CO

Rifle, CO

Glenwood Springs, CO

Durango, CO

Grand Junction, CO

Grand Junction, CO

Wheat Ridge, CO

Colorado Springs, $\mathrm{CO}$

Montrose, CO

Grand Junction, CO

Cortez, CO

Denver, CO

Boulder, CO

Rifle, CO

Rifle, CO

Denver, CO

Avon, CO

New Castle, CO

Delta, CO

Grand Junction, CO

Durango, CO

Grand Junction, CO

Denver, CO

Gunnison, CO

Gunnison, CO

Grand Junction, $C O$

Durango, CO

Gunnison, CO

Grand Junction, CO

Durango, CO

Rifle, CO

Montrose, $\mathrm{CO}$

Cortez, CO

Cortez, CO

Gunnison, CO

Boulder, CO

Rifle, CO

Crested Butte, CO

Montrose, CO

Glenwood Springs, CO

Carbondale, CO

Golden, CO 


\section{Vendor}

Grand River Institute

Grand Junction Area

Green International

Grand Junction Fire Department

Grand Junction Hilton

GTG-FOX Geotechnical

Gunnison Camera Center

Gunnison Chapter, American Red Cross

Gunnison City Times

Gunnison County

Gunnison Metal Shop, Inc.

Gunnison Trucking

Hansen Weatherport Corporation

Henry's Radio \& TV

Hewlett Packard

Holland \& Hart

HY-Way Feed and Ranch

IRS

Jack David

Jerry Greene, PE

Jim Dible Oil Co.

John Haines

John A. Wilson

John A \& Helen Dix

Johnson Construction Co.

Joyce Woodard

Kelco General Contractor

KLB

La Plata Electric

Ladonna Motel

Lambert \& Associates

Landmark Reclamation

Lions Club Intl.

Lotus

Lyons Safety

Magnum Electric

Maryhannah \& Charles

Mauch 1 Hour Photo

Melvin Seevers

Gunnison City Times

Mesa County Safety Council

Mesa Extension Fund

Mesa Family Practice

Mountain Communications

Mountain West Office Products

\section{Location}

Grand Junction, CO

Grand Junction, $\mathrm{CO}$

Denver, CO

Grand Junction, CO

Grand Junction, CO

Wheat Ridge, CO

Gunnison, $\mathrm{CO}$

Gunnison, CO

Gunnison, $C O$

Gunnison, CO

Gunnison, CO

Gunnison, $\mathrm{CO}$

Gunnison, CO

Gunnison, CO

Denver, CO

Denver, CO

Silt, $\mathrm{CO}$

Denver, $C O$

Gunnison, $\mathrm{CO}$

Gunnison, $\mathrm{CO}$

Grand Junction, CO

Glenwood Springs, CO

Gunnison, $\mathrm{CO}$

Rifle, $\mathrm{CO}$

Rifle, Co

Slick Rock, CO

Grand Junction, CO

Grand Junction, CO

Durango, CO

Rifle, CO

Montrose, CO

Golden, CO

Gunnison, $\mathrm{CO}$

Boulder, $C O$

Denver, CO

Grand Junction, CO

Rifle, CO

Grand Junction, CO

Grand Junction, CO

Gunnison, CO

Grand Junction, CO

Grand Junction, CO

Grand Junction, CO

Avon, $\mathrm{CO}$

Grand Junction, CO 


\section{Vendor}

Mountain Hotsprings Equipment

Mr. Carpet Wall to Wall

MSHA Fiance Branch

Munro Properties, Inc.

NAPA Auto Parts-Ace Hardware

Nationwide Advertising

North Avenue Furniture \& Appliances

NW Transport Service

OAG Official Airline

Office Machine Sales \& Services

Official Airline Guide

$P \& L$ Welding

Palisade Constructors Inc.

PC World

Plaza Engineering Supply

Powers Elevation Co.

Precision Scale

Public Service Co. of Colorado

QED Surveying Systems

Randall Industries

Random Access

Reams Construction

Recordmaster

Red Rocks Community College

Reed Constructors, Inc.

Reed Miller, Inc.

Resource Technologies

Respond Systems

Rifle Chamber of Commerce

Rifle Fire Protection

Rifle Fire Side Inn

Rifle Medical Association

Rifle Realty Inc.

Rocky Baldozier

Ronald A. Long

Roseberry Plumbing \& Heating

Roving Maintenance

Royce A. Dix

RTG

Rusk \& Rusk Court

S\&S Total Car Care

Safeway, Inc.

San Miguel Basin Forum

Scherry Simonson

Schmalz Construction

\section{Location}

Grand Junction, CO

Grand Junction, CO

Denver, CO

Grand Junction, CO

Gunnison, CO

Englewood, CO

Grand Junction, $C O$

Commerce City, CO

Boulder, CO

Montrose, $\mathrm{CO}$

Boulder, CO

Grand Junction, CO

Palisade, $\mathrm{CO}$

Boulder, $\mathrm{CO}$

Grand Junction, CO

Aurora, CO

Englewood, CO

Denver, CO

Grand Junction, CO

Grand Junction, CO

Englewood, $\mathrm{CO}$

Naturita, $\mathrm{CO}$

Grand Junction, CO

Lakewood, CO

Palisade, $\mathrm{CO}$

Grand Junction, CO

Denver, CO

Grand Junction, CO

Rifle, CO

Rifle, $\mathrm{CO}$

Rifle, $\mathrm{CO}$

Rifle, $\mathrm{CO}$

Rifle, CO

Westminster, $\mathrm{CO}$

Gunnison, CO

Durango, CO

Whitewater, $\mathrm{CO}$

Rifle, CO

Denver, CO

Grand Junction, CO

Rifle, $\mathrm{CO}$

Denver, CO

Nucla, CO

New Castle, CO

Gunnison, CO 


\section{Vendor}

Schmueser \& Associates

Schmueser, Gordon, Meyer

Search and Rescue

Secretarial \& Copying

Shaler Motel

Signpro

Slavens, Inc.

Spirit Express

SSD, Inc.

Summit Supply

Susan Good Associates

T/J Communications

The Citizen Telegram

The Denver \& Rio Grande

The Insulation Company

The Office Supply Store

The Paper Clip

The Sign Guys

The Sound Company

Tim's Tools

Tri County Fire

Turning Point Training

Two-Way Communications

U.S. West Cellular

U.S. Postmaster

U.S. Postmaster

U.S. West Communications

U.S. Postmaster

U.S. Government Printing

UNITEL, InC.

University of Colorado

University of Colorado

UPS

VALCO, Inc.

Vic's Photos

Video Training Source

Vo-Tech

Wagner Equipment Co.

Warning Lites \& Equipment

Waste Tech News

Water Clerk

Water Court

Webb Crane Service

Western Colorado Security

Western Implement Co.

\section{Location}

Rifle, CO

Glenwood Springs, CO

Wheatridge, CO

Gunnison, $\mathrm{CO}$

Rifle, $\mathrm{CO}$

Grand Junction, CO

Cortez, CO

Grand Junction, CO

Grand Junction, CO

Durango, CO

Steamboat Springs, CO

Grand Junction, CO

Rifle, $\mathrm{CO}$

Denver, CO

Rifle, $\mathrm{CO}$

Rifle, CO

Gunnison, $C O$

Crested Butte, CO

Grand Junction, $\mathrm{CO}$

Silt, $C O$

Rifle, CO

Aurora, CO

Grand Junction, CO

Denver, CO

Grand Junction, CO

Gunnison, CO

Denver, CO

Grand Junction, CO

Pueblo, CO

Grand Junction, $C O$

Denver, CO

Boulder, $\mathrm{CO}$

Arvada, CO

Gunnison, CO

Cortez, CO

Lafayette, CO

Delta, CO

Denver, CO

Grand Junction, CO

Denver, CO

Glenwood Springs, CO

Montrose, CO

Grand Junction, CO

Grand Junction, CO

Grand Junction, CO 
Western Slope Connections

Western Slope Fire and Safety

Western Valley Glass

Westhoff Electric

William B. Love Appraisal

Youngs General Contracting

Zee Medical
Gunnison, CO

Gunnison, CO

Rifle, CO

Silt, $\mathrm{CO}$

Cortez, CO

Grand Junction, CO

Aurora, CO 


\section{COMMON COLORADO VENDORS USED BY UMTRA VICINITY PROPERTY SUBCONTRACTORS}

\section{Name}

\section{A\&B Asbestos}

Ace Insulators aka Ace Insulation Co.

Atlas Mechanical Insulators, Inc.

Bernis Electric

BG Harrison Masonry

Brinkley Electric

Cedaredge Interiors

Cheyenne Mountain Electrical Contractors, Inc.

Connaway \& Co., Inc.

Eberhart Electric, Inc.

Eberhart Electrical

Elam Construction, Inc.

Falcon Plumbing \& Heating

G\&G Paving

Goodson Electric

Grasso Masonry, Inc.

Hazardous Waste Technologies

$J \& S$ Fence

Karnes Carpet World, Inc.

Lane \& Company

Lunsford Brothers Mechanical

MDR Corporation

Melgares \& Co.

Mike Peterson Masonry

Miracle Roofing

Monument KDK Trucking

Morgan Asphalt

Mr. Carpet

P. W. Stephens Contrators, Inc.

Skyline Contracting, Inc.

SOS Temporary Services

Taylor Fence

Technology Quest

Tematics, Inc.

United Companies of Mesa County, Inc.

Whitewater Building Materials Corp.

\section{Location}

Grand Junction, $\mathrm{CO}$

Grand Junction, $C O$

Loma, CO

Grand Junction, $\mathrm{CO}$

Grand Junction, CO

Grand Junction, $\mathrm{CO}$

Cedaredye, CO

Calhan, CO

Grand Junction, CO

Grand Junction, CO

Grand Junction, CO

Grand Junction, CO

Grand Junction, CO

Grand Junction, CO

Clifton, CO

Grand Junction, CO

Colorado Springs, CO

Grand Junction, CO

Grand Junction, CO

Grand Junction, CO

Grand Junction, CO

Northglenn, CO

Grand Junction, CO

Fruita, CO

Grand Junction, CO

Grand Junction, CO

Grand Junction, CO

Grand Junction, CO

Penrose, CO

Grand Junction, $C O$

Grand Junction, $C O$

Grand Junction, CO

Grand Junction, CO

Grand Junction, CO

Grand Junction, CO

Grand Junction, CO 


\section{COLORADO SUBCONTRACTORS USED FOR THE GRAND JUNCTION VICINITY PROPERTY PROGRAM}

Name

\section{Alpine CM}

Bayless \& Bayless

CG Construction

D\&L Construction

Diamond Back Service

DLB Unlimited

Francis Constructors

Fred Cunningham Construction

G\&G Paving

Joyner Construction

Kinder Coonstruction

M.A. Concrete Construction Co.

Mays Concrete

Mountain Region Corporation

Nelson Engineering

Parkerson Construction

Perrin Constructors, Inc.

Reed Constructors, Inc.

Skelton Construction Co.

Sorter Construction

Superior Contracting

West Hazmat Contracting, inc.

\section{Location}

Grand Junction, CO

Pueblo, $\mathrm{CO}$

Grand Junction, CO

Grand Junction, CO

Littleton, CO

Grand Junction, CO

Grand Junction, $C O$

Grand Junction, CO

Grand Junction, CO

Grand Junction, CO

Grand Junction, CO

Grand Junction, CO

Grand Junction, $C O$

Grand Junction, CO

Grand Junction, $C O$

Grand Junction, $C O$

Grand Junction, CO

Palisade, CO

Grand Junction, CO

Grand Junction, CO

Grand Junction, $C O$

Englewood, CO 
ATTACHMENT 3

EMPLOYMENT AND EARNINGS MULTIPLIERS 


\begin{tabular}{|c|c|c|}
\hline Region/industry & Earnings & Employment \\
\hline \multicolumn{3}{|l|}{ Energy and mining region ${ }^{\circ}$} \\
\hline New highways and streets & 1.959 & 2.222 \\
\hline Personnel supply services & 1.423 & 1.314 \\
\hline Engineering and architectural services & 1.625 & 1.924 \\
\hline \multicolumn{3}{|l|}{ Southwest agriculture and recreation ${ }^{b}$} \\
\hline New highways and streets & 1.674 & 1.917 \\
\hline Personnel supply services & 1.374 & 1.276 \\
\hline Engineering and architectural services & 1.557 & 1.842 \\
\hline \multicolumn{3}{|l|}{ Ski country region ${ }^{c}$} \\
\hline New highways and streets & 1.746 & 1.969 \\
\hline Personnel supply services & 1.327 & 1.255 \\
\hline Engineering and architectural services & 1.601 & 1.875 \\
\hline \multicolumn{3}{|l|}{ State of Colorado } \\
\hline New highways and streets & 2.610 & 2.967 \\
\hline Personnel supply services & 1.674 & 1.481 \\
\hline Engineering and architectural services & 2.207 & 2.588 \\
\hline
\end{tabular}

'Consists of Grand Junction, Maybell, Naturita, and Rifle.

Includes Durango and Slick Rock.

Includes Gunnison.

Note: These multipliers were developed at the state and regional level using 1989 employment and earnings data compiled by the U.S. Bureau of Economic Analysis. They are based on interindustry relationships contained in the most recent (1982) input-output accounts. 

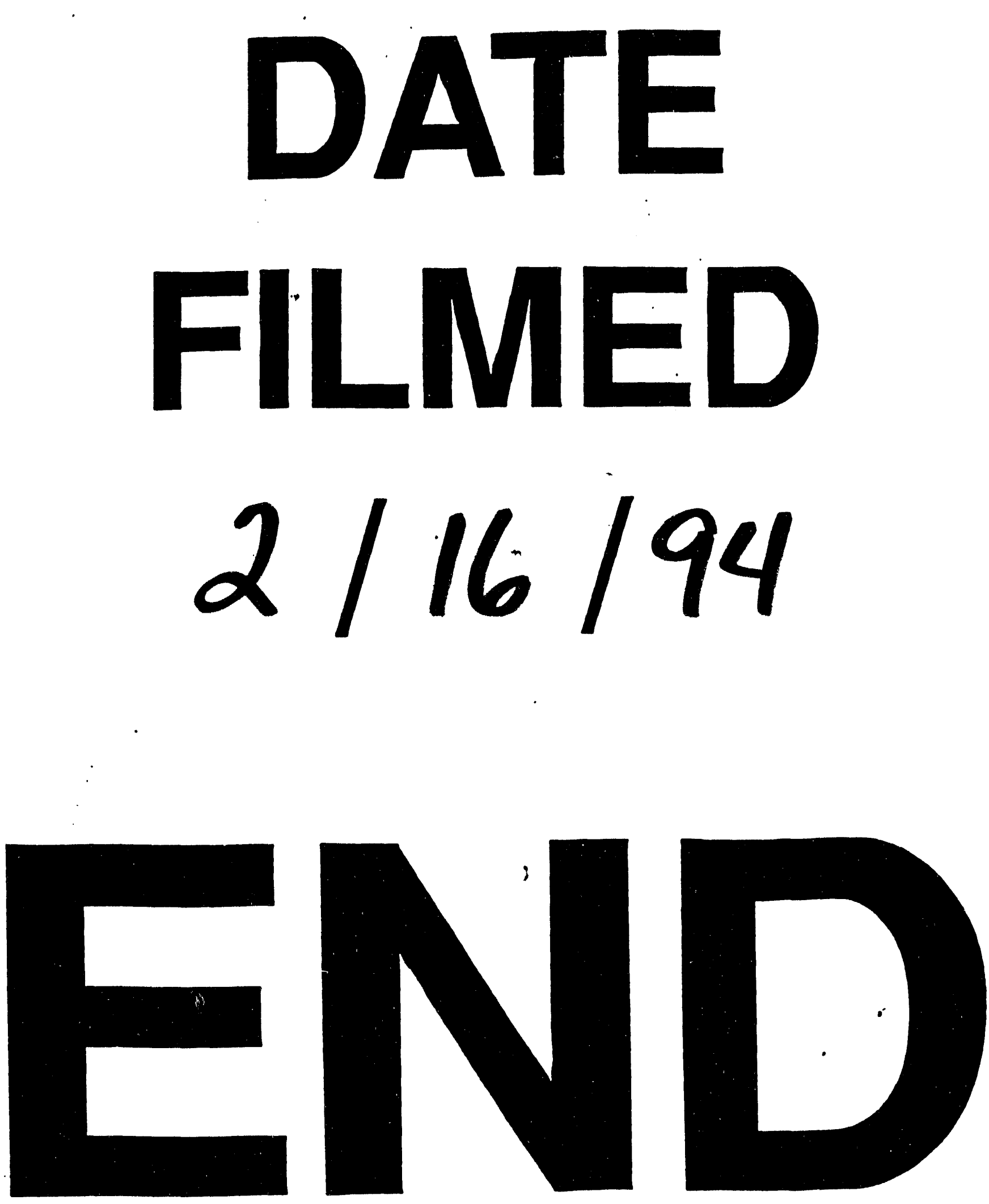
